\title{
Citizens' Initiative as a Factor in Educational Progress
}

\section{G. Stanley Hall}

To cite this article: G. Stanley Hall (1905) Citizens' Initiative as a Factor in Educational Progress, The Pedagogical Seminary, 12:4, 471-477, DOI: 10.1080/08919402.1905.10534672

To link to this article: http://dx.doi.org/10.1080/08919402.1905.10534672

曲 Published online: 30 Aug 2012.

Submit your article to this journal $\sqsubset$

Џ Article views: 3

Q View related articles ¿ 
By G. Stant,Ey HaI,I.

While improvements in school systems may be begun at many points, the greatest need, as well as the chief leverage, is to begin with the school boards. The last twelve or fifteen years have witnessed, in this country, a new movement to reduce their size. To select twenty representative cities, the following, have nine members on the Board: Springfield, Los Angeles, Duluth, Baltimore. St. Paul, Cleveland, Memphis and Washington have seven. Kansas City and Denver have six each. Five are found in Buffalo, Toledo, Rochester, Indianapolis, Minneapolis, New Haven and now Boston. San Francisco has four, while Albany and all the cities of the second class in the State of New York have only three. Of these twenty, I have visited all but four since their reform, and have been impressed both with their general excellence, for no other twenty could be selected that are on the whole so good, and with the uniform testimony to great improvement due to recoustruction. My correspondents in these twenty cities assure me that no breath of scandal has arisen under the new system, and I am told that there is no system in the country that has enlarged its Board within a decade. This movement is spreading rapidly, and has already reached several" score cities besides the above, while similar changes are under discussion in many, if not most, cities that retain the old system. Worcester's Board of twenty-four is already among the largest in the country for the size of the city.

Without exception, so far as I know, the reform has been initiated from outside the school system. It is generally a citizens' movement, and has usually been adopted only after a vigorous struggle with the representatives of the old order. Everywhere there have been the same objections, and everywhere the same triumphant answers to them.

I. The reduction in the size of the Board is called antidemocratic and the idea of many honest, well-meaning citizens is that a large Board is more like the old-fashioned town meeting and that to coucentrate so much authority in a very few hands

${ }^{1}$ Address before the Citizens' Educational Society, Worcester, Mass., May, I905. 
seems at first a risky step. The answer to this argument, which is overwhelming, is that, if only representative men could discuss and settle all school questions in public, the larger the body the better, but large Boards everywhere break up into small committees. Boston had 29; Worcester has I I Philaḑelphia had 37. No superintendent, no citizen, and even no reporter, can attend all these meetings, so they are usually in effect secret. And yet, in them all, important business is arranged, questions settled, plans matured; all trades and adjustments are pre-determined. Hence it comes that in the general meetings there is little to do but to take and record votes (I know of one single meeting in which over seventy votes were passed, after which a member told me that he knew the merits of only four questions, as that was all his committee contributed), and to talk for the benefit of the press, the constituents and the public generally; so that the true motives of measures are rarely apparent. In view of the vast sums of money expended annually for buildings, text-books, etc., and the ease with which jobbery and even corruption can be covered and individual responsibility evaded, there is constant temptation to crookedness. Thus the large Board in its actual operations is anti-democratic, and its real operations tend to become of the star chamber order.

Moreover, politics always tends to creep in. There is a general consensus that the last few decades have witnessed a general deterioration in the quality of members of the American school boards. More of them are unknown to the voters outside their own ward. It is the first step toward a political career and these little committees are particularly prone to patch and back at old rules and multiply new ones, so that now the body of enactments governing many of our city schools under the old system, instead of being plain and simple, sometimes comprises from one to three hundred pages of printed matter and presents ambiguities even if not inconsistently hard for a lawyer to master. Under the new system committees entirely cease and everything goes before the full Board, or there are a very few committees, where everything is open. Thus it is really the old system that is radically and essentially antidemocratic.

Again, it is objected that all parties and creeds should bave proportionate representation, and that the new Boards fail to secure this. This argument has great weight with partisans and religionists, but it is, if possible, more shallow and absurd than the other, for many of these new small Boards by distinct enactment must consist of representatives of each leading party and creed. San Francisco, with its Board of four, specifies that only two shall be of any one party; New Haven, with its 
Board of seven, specifies that not over four shall belong to the same party; and elsewhere provision is made for securing proportionate representation of Protestants and Catholics. For myself, I would go still farther, and welcome the best men, whatever their convictions. I am a Protestant and a republican, but I would prefer to send my children to a school where all the Board were Catholics or democrats, or both, if they were the best members of these persuasions, than where they were all of my own creed and politics but the worst, or even the average representatives. Many cities have risen above these questions, and are content with the best men.

II. Effective as a reduction in size has everywhere proven, it is not enough. The superintendent must be given more power in all purely educational matters. Education is now a profession, represented by chairs in most universities and by numerous and very expensive normal schools and colleges. The superintendent should be recognized as an expert, and instead of having all his duties minutely defined and prescribed, he should be free to use all his knowledge and ability for the good of the community. To do this he must first control the appointment and removal of teachers. It is hard for the great public to learn the vast difference between good and poor teachers or to understand how the quality of the teaching corps tends to distinctly deteriorate when this initiative is in the hands of the Board. A generation ago the Boards examined even graduating classes at normal schools, and gave or withheld diplomas accordingly. The best and not the worst teachers were selected for home consumption. I know there have been superintendents who illustrate the adage, "He who depends, defends," and have upheld a usage which took from them all responsibility of appointment. It is superintendents from these new cities that have this power that are now choosing and taking away the best teachers from the schools under the old system, where it is far easier to drop a good teacher who depends upon merit for his or her place, than a poor one who cultivates "pull." Those who are inwardly conscious of their own weakness often devote themselves to cultivating influence, until it becomes almost an impossibility to drop the worst, while the best are ever harder to keep. No wonder the best superintendents gravitate to cities where they can choose their own teachers, selecting the best wherever they are to be found.

Again, the superintendent should determine not only the courses of study but the text-books. There are vast differences between good and bad ones. Some are expressly made according to an elaborate receipt designed to make them sell to the ignorant, and sometimes venial, text-book committees. More- 
over, there is an innate contradiction in giving the superintendent the power to arrange the course of study and withholding the power of selecting all text-books. In some subjects the worst text can be bad beyond the power of description, while others open up topics easily and naturally, and make for mental economy and progress up to the grades, and bring out all the powers of the teacher and the pupil.

To this end, the superintendent should be selected with great care, for here, too, quality differs vastly, should be given a generous term, and also freed from the duty of educating new members of the Board each year, attending committee meetings, sitting on the anxious seat, and feeling himself essentially a servant liable, at least annually, to be discharged with or without cause.

III. A third reform, which has often-not always-gone with the preceding, but always should, is the separation of the busivess from the professional management of the schools. The erection of buildings, all changes in them, or grounds, the purchase of supplies, etc., should be in the hands of a trained business man, who should be on terms of friendly co-operation with the superintendent, but accountable to the Board. Various devices have been adopted to secure the management of school business upon the same principles which are recognized in private business. I have visited various cities where, within a decade or less, a judicious system of locations for new buildings, and a sensible plan of their construction, a great improvement on preceding schemes, has also resulted in very great economy. Sometimes where members of the Board undertake this work, they receive a salary. This has given rise to the objection that the new system is expensive. The contrary, however, is the case. The city of Rochester, which has now an admirable system, actually turned back into the treasury the first year after the new scheme went into operation, $\$ 81$,ooo. While such a per cent. of saving is exceptional, increased economy is the rule. Even in those cases where the budget is not reduced, far better service of every kind is obtained for the money. And this is true economy. It is precisely here that, in some cities, the rub has come, for this involves the abolition of favoritism, jobbery, and pulls, in all the matters involving contracts for material and labor, and secures the holding of each contractor and workman to his work by daily and detailed supervision. The difference between the methods of constructing schools and constructing dwellings and business houses, by those who own and occupy them, is great.

IV. Another reform that has often been found very helpful is a special election for the school board; sometimes a separate day, and sometimes only another polling place near by, or per- 
haps in the same room but under independent control. This factor seems to work well, but has hardly been tried sufficiently yet to reveal all its possibilities. Every degree of separation in space or in time tends to divorce education from politics and bring to the polls those most interested in school matters. In some communities women are allowed to vote for school officers, and so far this seems to have worked well. A separate election, however, such as now prevails in Indianapolis, Colorado, and elsewhere, is at least a promising experiment.

Closely connected with this is the separation of the school board from the city goverument. Where educational matters are controlled by one body and the financial support of schools by another, all kinds of friction and even abuse creep in : as in a large city recently, where school supplies were diverted by the council and instead of shortening the school year, as has sometimes been done, children were massed sixty in a room and many teachers released early in the year in order to avoid a deficit.

Now no one of these improvements is sufficient of itself to insure real effectiveness, for great is the influence of lust of office and power, and often of spoils. There is no more clear and certain lesson from the whole history of education than that it always and everywhere tends by an iron law to degenerate in quality. I cannot think of a single great reform that has ever been effected where the initiative and the carrying out of it sprang from within the system itself. The great reformers have for the most part been philanthropists, patriots, or at any rate, not plain teachers by vocation. Thus such a function as your body seeks to exercise is essential. There are American cities to-day in which the Woman's Clubs have abandoned every other function except that of improving the public schools, and in some cases they have effected very great and beneficent changes:- introduced the kindergarten; broadened the scope of manual and industrial training; improved the grounds; decorated the walls of the schoolrooms with works of art, sometimes quite costly; secured the nomination of good men or women on the Board; improved hygienic arrangements; aroused public sentiment; rallied and organized the parents to meet weekly or monthly in every school building; improved evening schools; introduced nature study, etc.

These methods are all in the direction of simplification and increased directness. Everything is open to the public and to the press. It is the introduction of plain business common sense, and wherever introduced, has behind it the intelligence of the community and arouses local pride and new public interest in the school. It is supported by every argument that is slowly working out municipal reforms in cities like St. Louis, Chicago and Philadelphia. It always brings excellent, if not the very 
best, talent and experience in the community into the service of the schools, and is certain to prevail just as soon as parents understand their own interests and those of their children.

Finally, the best answer to the question, what your society can do, is found in the statement of what other societies have done. Some of them have committees on the work of similar societies elsewhere, to bring before the members promptly knowledge of every new departure. Perhaps they send delegates to visit these societies and to attend and report their meetings. Some of them have central meetings to compare notes with delegates from other similar societies. What has been accomplished in Brookline, Brooklyn, Philadelphia and elsewhere is certainly surprising. Again, lecture committees provide courses each season, sometimes by specialists in education and science, art, etc., and sometimes lectures with the stereopticon for school children. Others have committees on the relations of the work of the society to the community, whose duty it is to interest the press and supply them with information and to canvass for membership. Others have playground committees that consider the needs of municipal gymnasia, improve, enlarge or extend facilities for playing in the school grounds, and on roofs, erect sheds for gymnastics in bad weather, etc. Art committees do several different things in different places. They collect pictures, photographs, mount and group them, cutting from weeklies and monthlies, for which they advertise, and arrange them so as to illustrate themes in history, art, nature study, literature, biography, geology, botany, etc. Sometimes these portfolios are circulated in the children's reading room of the library, and teachers can indicate the class of pictures they desire. I have seen one school that, as a result of some years of work by teachers and friends, had, I should say, six or eight thousand pictures, arranged to supplement the work of the school. Again, art committees solicit subscriptions for pictures, photographs, prints, drawings and statuary for the schoolrooms. Even loan exhibitions have been conducted by these committees for the benefit of the schools and perhaps in the high school hall. A permanent museum of industrial art or children's productions on paper and wood, etc., has been established in at least one city. History committees devise means for interesting both parents and pupils in local history, and perhaps print pamphlets outlining the history of the town and its vicinity and suggesting historic excursions, collecting slides, and sometimes even new material has been gathered, old sites marked and literature listed. This has stimulated local pride. Science committees suggest topics, often of local interest,-water sheds, native flowers, birds, trees, animals; study the telephone, fire, electric car service, ventilation, hygiene or astronomy; print charts of local 
objects of scientific interest; collect scientific toys and pictures; conduct popular lectures with experiments; and have also occasionally contributed apparatus. Physical and manual training committees have investigated conditions in schoolrooms, interested physicians to gather data, made recommendations for hygienic improvements, reports on the state of athletics, brought experts to lecture on manual training, and gathered educational suggestions for such courses from the people and the industries of the town, etc. Other committees have devoted themselves to the study and help of boys' clubs and perhaps started new ones, assisting them in the way of procuring quarters and in useful expenditures of their energies in debate, etc. Mothers' meetings have been arranged in the schoolroom where teachers and others were present, and practical topics like children's dress, lunches, home duties, toilet, health, etc., were discussed. Occasionally special studies of children have been instigated by these committees.

I find that there have been committees or lectures or courses under their auspices on the reading of children, home study, recreation, music, the relations to the public library, storytelling, the flora and the fauna of the region, etc. The object throughout is to bring the parents and the school and teachers nearer together, to create intelligent interest in the welfare of the school, to inform the public as to present theories and practices and thus create a sound public opinion. Social meetings are often held. The essential feature of these associations always is work, which is largely done by standing committees continued from year to year for specific ends.

If this society is to accomplish results, it seems to me it should address itself to a definite programme of work, with definite goals. Merely to edify and instruct each other, or even to inform the community is well, but I think the programme of all other societies of this kind, that $I$ know, is more definite and involves much more work. But it must not be forgotten that your work is just beginning. Your ends and purposes are the best things in the field of public education that have come to this city since my residence here. May you have the wisdom and energy in the face of the great work before you, so sorely needed here, to push on to complete success. 